\title{
TRADITIONAL PHYTOTHERAPY OF SOME MEDICINAL PLANTS USED BY THARU AND MAGAR COMMUNITIES OF WESTERN NEPAL, AGAINST DERMATOLOGICAL DISORDERS
}

\author{
Anant Gopal Singh* and Jaya Prakash Hamal** \\ *Department of Botany, Butwal Multiple Campus, Butwal, Tribhuvan University, Nepal. \\ ** Department of Botany, Amrit Science Campus, Tribhuvan University, Kathmandu, Nepal.
}

\begin{abstract}
Ethnobotany survey was undertaken to collect information from traditional healers on the use of medicinal plants in the treatment of different skin diseases such as cuts and wounds, eczema, boils, abscesses, scabies, dog and insect bite, ringworm, leprosy, burns, blisters, allergy, itching, pimples, leucoderma, prickly heat, warts, septic ulcers, and other skin diseases in western Nepal during different season of March 2009 to May 2011. The indigenous knowledge of local traditional healers having practical knowledge of plants in medicine were interviewed in 10 villages of Rupandehi district of western Nepal and native plants used for medicinal purposes were collected through questionnaire and personal interviews during fieldtrips. A total of 60 plant species of 43 families are documented in this study. The medicinal plants used in the treatment of skin diseases by tribal's are listed with botanical name (in binomial form), family, local names, habit, availability, parts used, and mode of preparation. This study showed that many people in the studied parts of Rupandehi district continue to depend on the medicinal plants at least for the treatment of primary healthcare.
\end{abstract}

Keywords: Tharu and Magar tribes; Traditional knowledge; Dermatological disorders; Medicinal plants; Western Nepal.

\section{INTRODUCTION}

The knowledge of medicinal plants has been accumulates in the course of many centuries based on different medicinal systems such as Ayurveda, Unani, and Siddha. In Nepal, it is reported that traditional healers use 1792 plant species of medicine (Baral and Kurmi, 2006). During the last few decades, there has been an increasing interest in the study of medicinal plants and their traditional use in different parts of the world (Lev, 2006). Documenting the indigenous knowledge through ethnobotanical studies is important for the conservation and utilization of biological resources.

In traditional systems, the plants have been used in successful management of various disease conditions like respiratory tract infection, gastrointestinal problems, dermatological disorders, and in the treatment of hepatic and cardiovascular disorders (Sen, 1993).

The knowledge of tribal has, associated with the traditional healing practices, using wild plants, is now fast disappearing due to modernization and the tendency to discard their traditional life style and gradual migration to the main stream. There is an urgent need to study and document the precious knowledge for posterity. According to World Health Organization, more than $80 \%$ of the world's population relies on traditional herbal medicine for their primary healthcare. In view of exploitation and conservation of folk knowledge, an attempt has been made to study the ethnobotanical aspects from the Rupandehi district in western Nepal.

Aim of the present study is to highlight the traditional uses of some medicinal plants in western Nepal for the treatment of skin diseases. To document the natural resources, use pattern of the study area and indigenous knowledge associated with them. To encourage the local communities especially the younger generation to propagate and protect the medicinal plant wealth in the study area.

Skin diseases are of common occurrence among the rural masses due to poor hygienic conditions, poor

Author for correspondences: Anant Gopal Singh, Department of Botany, Butwal Multiple Campus, Butwal, Tribhuvan University, Nepal. E-mail: agsingh26@rediffmail.com. 
sanitation facility, and contaminated water. Traditional herbal medicines used by different communities play an important role in alleviating such skin diseases. They are safe, effective, and inexpensive and in many cases, the only method of medication.

\section{MATERIALS AND METHODS}

\section{Study Area}

Rupandehi is botanically rich district in western Nepal which is situated in between $83^{\circ} 27^{\prime} .955^{\prime \prime}$ to $83^{\circ} 28^{\prime} .255^{\prime \prime}$ E longitudes and $27^{\circ} 40^{\prime} .016^{\prime \prime}$ to $27^{\circ}$ 40 '.252" N latitudes and covers an area of $1360 \mathrm{~km}^{2}$ (DDC, Rupandehi, 2007). The district is bounded by hilly districts (Palpa and Arghakhanchi) in North, by Mahrajganj district of Uttar Pradesh (India) in South, by Nawalparasi district in East and by Kapilvastu district in West (Figure-1). Rupandehi district has a humid tropical climate with maximum temperature beyond $40^{\circ}$ $\mathrm{C}$ during summer (May-June) and below $10^{\circ} \mathrm{C}$ during winter (December- January) and annual rainfall is about $1250 \mathrm{~mm}$. Geographically it is divided into Chure region (14.5\%); Bhabar region $(0.6 \%)$ and Terai region $(84.9 \%)$. The climatic condition of the district is tropical type and Sal (Shorea robusta) forest is dominated along with other. The total population of the district was 7, 08,419 (CBS 2001). The Tharu and Magar are the ethnic societies of the study area. They live in association with Chhetri, Thakuri, Brahmin, Gurung, Damai, Yadav, Kami, Kurmi, Teli, Majhi, and others. In different villages Magar and Tharu communities living together in northern side but in southern foot hills of the Himalayas Tharu community dominated on other casts while Magar community prefers Northern side of IndoNepal border for settlement.

The Tharu and Magar communities of the study area prefer traditional medicinal practice to the modern medicinal system because they know more about the medicinal plants which are easily available in their locally area and herbal formulations are comparatively cheaper and free from the side effects. The Tharu and Magar communities of the study area are not exception to the present stream of modernization and traditional medicinal practice seems to be disappearing among the ethnic communities of the study area. As indigenous knowledge on usages of medicinal plants is transmitted without any systematic process, and younger generations of the communities are not interested in traditional healing system because it has no/very little scope for money, so they engage themselves in other occupations.

\section{Local traditional healers}

Local traditional healers such as Tharus and Magars, having practical knowledge of plants in medicine, were interviewed in 10 villages (Saljhandi, Dudhraksh, Rudrapur, Parroha, Semlar, Motipur, Manpakadi, Sou.

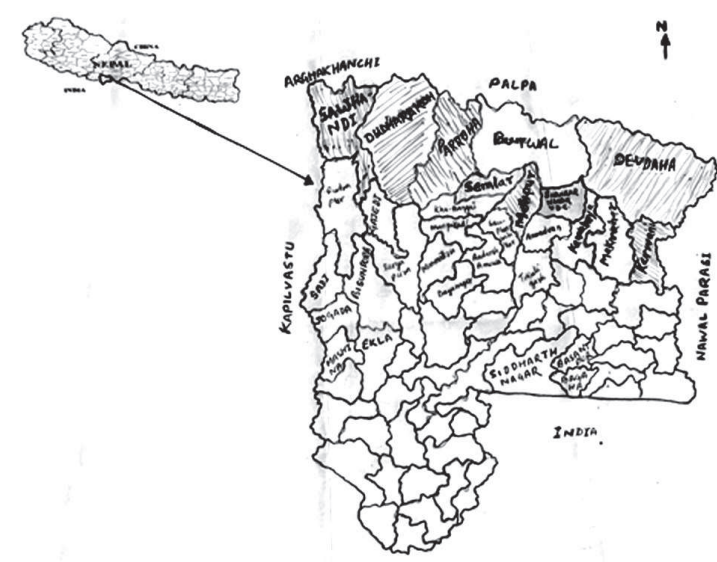

Figure 1: Map of Nepal showing Rupandehi district with study areas with labeling

Pharsatikar, P. Amuwa, and Devdaha) of the district during March 2009 to May 2011. During the course of the study, three field trips were carried out in the study area. Method of selecting informants depends upon the distribution of local people having folk knowledge. They were requested to collect specimens of the plants they know or to show the plant species on site. These informants were traditional healers themselves or had tradition of healing in their families and had knowledge of the medicinal use of plants. The wealth of medicinal plant knowledge among the Tharu and Magars of this district is based on beliefs and observations. This knowledge has been transmitted orally from generation to generation, however it seems that it is vanishing from the modern society since younger people of Tharu and Magars communities are not interested to carry on this tradition.

Based on language, customs, and geographical distributions, the Magars are divided into Barha Magarant- Magar, Atha Magarant- Magar, High mountain- Magar, Chhantyal, and other Magars (Manandhar, 2002). However, these groups do not differ in their original traditions and other social affairs. Given the fact that Magars are the subsistence farmers, they interact with their environments, eking out their living while managing, protecting, and utilizing the natural resources in their respective environments, both men and women use their own level of knowledge as they have learned in their communities.

The Tharus are famous for their ability to survive in the moist terai region, which is deadly to outsiders due to malaria. In 1902, a British observer noted, "Residences of plain and hill generally die, if they sleep in an open area in the terai between June to November, where as Tharu community was totally immune against malaria (Gunerantnne, A., 2002). They are farmer by occupation and cultivate rice, pulse, wheat, oil seeds, corn and lentils but also collect forest product such as wild fruits, vegetables, medicinal plants and material to build their houses, hunt wild animals, fishes, and snails. 
Generally Tharu tribes use varieties of wild plants in traditional ways for their daily requirements as well as primary healthcare.

\section{Interview with traditional healers}

Adopting the methods of Martin (1995) ethnomedicinal data were collected through general conservation with the informants. The questionnaires were used to have information on medicinal plants with their local names, habit, wild or cultivated, availability, parts used, mode of preparation, and use. A total of 20 informants were identified between the ages of 31 to 72 . They were selected based on their knowledge of medicinal plants either for self medication or for treating others. Informants were asked and requested to come to field with us and show the plants with local name, the species mentioned by the informants were taxonomically identified.

\section{Preservation of plant specimens}

The collected plant specimens were brought to the laboratory and processed for herbarium preparation following (Rao and Sharma, 1990; and Woodland, 1997) and identified with the help of available floras and other potential literatures (Polunin and Stainton, 1984; Stainton, 1988; Noltie, 1994; Ross, 1999; Rajbhandari, 2001; and Manandhar, 2002 and Rao, 2004) and the name of identified plants were assigned according International Plant Names Index (2008) and submitted in the department of Botany, Butwal Multiple Campus, Tribhuvan University Nepal for future references.

\section{RESULT}

In the present study 60 medicinal plants were collected for cure of different skin diseases from 10 villages (Saljhandi, Dudhraksh, Rudrapur, Parroha, Semlar, Motipur, Manpakadi, Sou. Pharsatikar, P. Amuwa, and Devdaha) in Rupandehi district. The results of this study are presented in Table 1 and the medicinal plants are arranged in alphabetical order. Plant species, which are used in traditional medicines, are enumerated with their botanical and local names, family, voucher number, habit, habitat, and use of plant parts in the treatment of various skin diseases. The growth forms of collected plant specimens were show in figure- 2 and plant parts, which were used as medicine showed in figure- 3 .

\section{Ethnobotanical observations}

$>\quad$ Tharu and Magars are good herbalists. Plants are used in different forms such as juice extracts, decoctions, pastes, infusions, etc.

$>$ A juice is extract is prepared by grinding the cleaned plants or plant parts with water; the extract is used after have been filtered.

$>$ A decoction is obtained by boiling the plants or plant parts in water.

A paste is made by crushing small plant parts with water and making this into a soft mass.

An infusion is prepared by soaking the cleaned plant or plant parts in water for a few hours or days; afterwards it is filtered and used.

> A list of medicinal plants with binomial, family, local name, useful parts, habit, wild/cultivated and medicinal uses is provided below in table 1 .

\section{DISCUSSION}

The recorded ethnomedicinal plants were used in the treatment of various skin diseases such as cuts and wounds, eczema, boils, burns, abscesses, scabies, dog, and insect bites, ringworm, septic ulcers, allergy, pimples, leucoderma, prickly heat, warts, and inflammations. Majority of plant species described in the present investigation was used in the treatment of cuts and wounds, eczema, boils, dog and insect bite, abscesses, scabies, ringworm, and pimples. Most of the herbal remedies were taken externally in the form of paste. The plant parts were crushed and made into paste for application over the area of the diseases. In some cases along with plant parts a little amount of salt, oil, or ghee was used. This addition might be to enhance the efficacy of herbal remedies or to make the remedy more palatable masking the undesirable taste when taken orally. The medicinal plants are usually collected from wild habitat as and when there is a need. Many of the information reported in this study concerning with skin diseases are Amaranthus tricolor, Anagalis arvensis, Calotropis procera, Cheilanthus tenuifolia, Eleusine coracana, Gloriosa superba, Mirabilis jalapa, Nerium oleander, Premna barbata, Pterocarpus marsupium Wedlandia puberula, and Zizyphus rugosa etc are found to be new in the literature of Nepalese Medicinal plants and deserves further study.

The information provided in the paper is limited and there is a scope to initiate further ethnobotanical study among the communities to gather information as far as possible. The medicated claims incorporated in the study need to be evaluated to discover their potentiality as drugs. There is an urgent need to explore and document the ethnomedicinal plants used by the different communities of Rupandehi district before such knowledge vanishes. 
Scientific name, family, local name, and voucher number

Abrus precatorius L., Fabaceae, Ratti (Th), Raatogedi $(N / M)$.

AGS-92

Achyranthes aspera L.,

Amaranthaceae, Apamarga (M),

Datiwan (N).

AGS-33

Acmella calva (DC) Jansen.

Asteraceae, Marethi (N).

AGS- 121

Acorus calamus L., Acoraceae, Bojho (N), Bojha (M).

Wild Herb/

Leaf

Wild Herb/

Entire plant

Wild Herb/

Rhizome

AGS- 71

Adiantum capillus-veneris L., Adiantaceae, Pakhaale Uneu (N/M). AGS-162

Ageratum conyzoides L., Asteraceae, Ganaune ghans (M), Gandhaula (Th).

AGS- 49

Albizia lebbeck (L.) Benth. Fabaceae, Siris $(N / M / T h)$

AGS-350

Alstonia scholaris (L.) R. Br., Apocynaceae. Chhatiwan (N/Th),

AGS- 132

Alternanthera sessilis (L.) R. Br. ex DC. Amaranthaceae. Bhringi Jhar (N), Garri (Th).

AGS- 106

Amaranthus tricolor $L$.

Amaranthaceae, Raato Latte (N)

Chaulai (Th).

AGS- 57

Ampelocissus divaricata (Wall. ex Lawson) Planch, Vitaceae. Airi Lahara (N), Pureni (M).

Wild Tree/ Leaf, and Stem bark

Wild Treel Stem bark and Leaf

Wild Herb Entire plant parts

Wounds and sores (Sapkota, 2008)

Scabies (Gurung, 2003, Joshi and Joshi, 2007).

cular swelling (Manandhar, 1998), Eczema (Joshi and Joshi, 2007), Cuts (Uprety et al. 2010).

Toothache and Piles (Panthi and Chaudhary, 2003).

Skin diseases, bronchitis, Toothache (Adhikari, 2003).

Snake bite and Scorpion sting (Kunwar et al., 2008).

Cuts and wounds (Mahato and Chaudhary, 2003, Uprety et al. 2010), Infection between toes (Singh et al., 2012).

Boils (Dhami, 2008), Skin diseases (Singh et al., 2011 c)

AGS- 124 .

Anagalis arvensis L. Primulaceae. Armale (N). AGS- 355

Ananas comosus (L.) Merr. Bromeliaceae. Bhuin Kathar (N/M) AGS- 336

Annona squamosa L., Annonaceae. Sitaphal (N). AGS- 129
Wild Trailing herb/Root,

Fruit

Wild Herb/Leaf

Scorpion bite (Manandhar, 1993)

Wild herb/ Entire plant

Cultivated Herb/ Fruit

Wild, small sized tree/ Leaf and Seed
Blood purifier and indigestion (Singh et al., 2011 a).
Method of crude drug administration

Fresh leaf paste is warmed gently and applied over boils.

*Seed paste applied externally to treat eczema.

Seed paste mixed with root paste of Chitu (Plumbago zeylanica L.,) and is applied externally on affected parts of leucoderma.

Leaf crushed and mixed with cow ghee is used in deep cuts and wounds.

Entire plant parts crushed and made paste with water and are applied externally on different skin diseases.

Rhizome paste is applied externally to cure scabies. *Rhizome powder used to eliminate dandruff.

Leaf paste is applied externally to stop bleeding from fresh cuts.

Leaf juice and leaf paste applied on skin burns, cuts, wounds, boils and muscular pain.

The leaves are crushed and used as poultice for boils, sores, and swollen feet.

Decoction of leaves is applied externally on the affected part of the skin diseases.

Juice of the stem bark is applied externally on the ringworm, scabies, and septic ulcers.

*Leaf poultice is applied over muscular swelling and boils.

Bark paste mixed with mustard oil, applied externally on infected area in skin diseases.

Bark and leaf paste is applied on infectious wounds.

The latex is applied to wounds and boils.

Juice of entire plant part applied externally on affected parts to cure scabies.

Leaf paste is applied externally on abscesses and septic ulcer for quick healing.

The paste of leaf with a pinch of turmeric powder is applied on the face for curing pimples.

Root paste applied externally on infected area in skin diseases.

Fruit juice is used in skin diseases.

Juice of entire plant applied topically in skin diseases and decoction is used in snake bite.

Fresh fruit juice applied topically in skin diseases.

Poultice of leaves is applied over boils and sores.

Seed powder is poured over the skin diseases of domestic cattle. 
Arisaema tortuosum (Wall.) Schott, Araceae. Baanko (N). AGS- 403

Artocarpus heterophyllus Lam., Moraceae. Rukhkatar (N). AGS- 172

Basella alba L., Basellaceae. Poi sag (N/M). AGS- 124

Bassia longifolia Koenig, Sapotaceae. Mahuwaa (N).

AGS- 90

Bauhinia purpurea L., Fabaceae. Tanki (N/M). AGS- 110

Begonia picta Smith, Begoniaceae. Makarkanchi (N)/ Magar Kaanche (M). $A G S-183$

Berberis asiatica Roxb. ex DC, Berberidaceae. Chautari (N)/ Chautra (M). $A G S-135$

Blumea lacera (Burm.f.) DC. Asteraceae. Kukur ghans (N/M)

$A G S-119$

Boerhavia diffusa L., Nyctaginaceae. Punarnaava (N).

AGS-91

Bryophyllum pinnatum (Lam.) Oken, Crassulaceae. Ajammari Jhar (N).

Patthar chatta (M).

AGS- 128

Calotropis procera (Aiton) Dryander, Asclepiadaceae. Seto Aank (N/M).

AGS-184

Cannabis sativa L., Cannabaceae. Bhang, Ganja (N/M).

AGS- 192

Cassia occidentalis L., Fabaceae. Chakmake (N).

AGS- 134

Cassia tora L., Fabaceae. Tapre (N), Chhinchhine Jhar (M). AGS- 138

Centella asiatica (L.) Urban, Apiaceae. Ghodtapre (N), Tapre jhar (M).

$A G S-36$
Wild shrub/

Latex

plant

Wild herb/

Rhizome

Headache and Toothache

(Rokaya et al., 2010).

Cultivated treel Skin diseases (Rai, 2003)

Boils, pimples, cuts and wound (Dhami, 2008).

Wild climbing Insomnia (Acharya and Pokhrel, herb/Leaf 2006).

Wild tree/ Bark Cough, cold, and bronchitis and seed. (Rai, 2003).

Wild tree/ Leaf Rabies (Devkota and Karmacharya, 2003); Boils (Joshi and Joshi, 2007).

Wild herb/ Pained nipples (Coburn, 1984); Entire plant Peptic ulcers (Manandhar, 1993).

Wild shrub/

Wounds and inflammation

Stem bark and

( Old ulcers (Joshi and Joshi, 2007).

Wild herb/Leaf Cutaneous infection (Rai, 2004); Cuts (Acharya and Pokhrel, 2006)

Wild herb/Root Pimples (Joshi and Joshi, 2007); Bronchitis and redness of eye (Singh et al., 2011 b)

Wild succulent Wounds and Boils (Singh et al., herb/Leaf 2011 b)

Wild herb/ Young shoot

Cuts and wounds, skin diseases (Devkota and Karmacharya 2003); Healing wounds and (Watanabe et al., 2005): Scabies (Joshi and Joshi, 2007); Control bleeding (Kunwar et al., 2010).

Wild herb/Leaf Scabies (Panthi and Chaudhary, and Seed 2003); Skin infection and inflammation (Rai, 2004); Ringworm and itch (Acharya and Pokhrel, 2006).

Wild herb/ Root, leaf and Ringworm and itch (Acharya and Pokhrel, 2006);

Leucoderma, leprosy, and itches (Joshi, 2008); Skin diseases and arthritis (Singh et al., 2011 a).

Skin diseases (Mahato, 1998); Antidote to poison, cuts and wounds (Balami, 2005), Leprotic wounds (Joshi and Joshi, 2007).
Rhizome paste is applied on body part stung by scorpion.

Leaf paste is applied over boils, cuts and wounds, and skin diseases.

Leaf paste is applied externally on skin allergy for quick relief.

Bark paste is applied externally on cuts and wounds to stop bleeding.

Seed oil is applied externally on skin diseases.

Leaf paste is applied externally over skin diseases.

Plant paste is applied to stop bleeding from cuts and wounds.

Plant paste applied externally on ringworm and scabies.

Yellow stem bark is crushed mixed in water and make a paste that applied externally on pimples, itches, and scabies.

Root paste applied externally on wounds and inflammation.

Leaf juice along with Chini jhar (Scoparia dulcis

L.) is applied on the bruise, cuts, and wounds.

Leaf juice is applied on bruises of toe, cuts and wounds

Root paste is taken orally to cure pimples.

Leaf paste applied on abscesses to remove pus. Burnt leaves are externally applied in wounds, boils, and skin burns.

A fresh leaf is warmed gently and wrapped on pussy wound to remove pus.

*Milky latex mixed with salt is applied on scabies, ringworm, boils, blisters, and abscesses to removes pus.

Decoction of young shoot is applied on cuts and wounds to stop the bleeding and work as antiseptic.

Leaf paste is applied externally on skin infection and inflammation.

Seed paste with mustard oil is applied externally on eczema and skin diseases.

Paste of leaves and seeds with Besar (Curcuma longa L.,) applied externally on skin to cure skin diseases and eczema.

Paste of root is applied on affected area to treat ringworm.

Plant juice is applied to treat cuts and wounds.

Leaf paste is applied on wounds for quick healing.

Paste of entire plant is applied on affected area to cure ringworm. 
Cheilanthus tenuifolia (Burm.f.) Sw., Pteridaceae. Raani sinka (N). AGS151

Cissampelos pareira L.,

Menispermaceae. Batule Lahara (N); Badal pate (M).

$A G S-182$

Clerodendrum viscosum Vent Verbenaceae. Bhait (N), Dhusi (Th).

$A G S-148$

Datura metal L., Solanaceae. Kalo Dathuro $(N / M)$

AGS-03

Eclipta prostrata (L.,) L., Asteraceae. Bhringraaj (N/M), Bhangaraila (Th).

$A G S-22$

Eleusine coracana (L.) Gaertn.,

Cultivated

Poaceae. Kodo (N/Th), Rangkwa (M). herb/Seed

AGS- 156

Euphorbia hirta L., Euphorbiaceae. Dudhejhar (N).

Wild herb/ Entire plant

$A G S-222$

Ficus benghalensis L., Moraceae. Bar (N), Paramsing (M), Bargadh (Th).

AGS-30

Ficus religiosa L., Moraceae. Peepal (N)/Peepar (M)/Pipra (Th).

AGS- 331

Gloriosa superba L., Liliaceae Karihar (Th), Agnisikha (N).

AGS- 31

Heliotropium indicum $L$. Boraginaceae. Haati sude (N).

AGS- 186

Ipomea aquatica Forssk. Convolvulaceae. Karmaiya sag (Th), Kerunga sag (N). AGS- 16

Kaempferia rotunda L. Zingiberaceae. Bhuin Champa (N). Tuber

Wild aquatic herb/Stem and leaf

Wild treel Latex, stem bark

Wild tree/ Stem bark, and leaf

Wild climbing herb/Rhizome

Wild herb/ Entire plant

Cuts and infection on tongue (Acharya and Pokhrel, 2006)

and wounds (Manandhar, 1993) Snake bite (Devkota and Karmacharys, 2003); Burn, wounds, and boils (Joshi and Joshi, 2007)

Boils and wounds (Parajuli, 2001); Healing of foot crack (Panthi and Chaudhary, 2003); Scabies (Joshi and Joshi, 2007).

Skin diseases (Manandhar, 2002, Rai, 2003); Scabies (Josh and Joshi, 2007); Cuts and wounds (Bhattarai et al., 2009).

AGS- 204

Lawsonia inermis L., Lythraceae. Mehandi (N/Th). AGS- 170

Leucas cephalotes (Roth.) Spreng. Lamiaceae. Dron pushpi (N), Gumma (Th).

Leaf, and

tender shoot

Wild shrub/ Heal cracks, and mud infection Entire plant (Acharya and Pokhrel, 2006), cuts, wounds, and boils (Dhami, 2008)

Burns (Panthi and Chaudhary, 2003).
Fronds cut into pieces, made to a paste, applied on abscesses in the form of poultice to remove pus.

Paste of entire plant parts applied externally on affected areas of skin irritations, ringworm, burns, and wounds.

Root and leaf paste applied on affected area to treat eczema and ringworm.

Leaf latex applied in fresh cuts and wounds to check bleeding.

Seed powder boiled in mustard oil and applied over affected parts to treat scabies and boils.

Plant paste is applied over cuts, wound, skin diseases, and pimples as antiseptic.

Crushed leaves are applied between toes and heal against fungal disease

Paste of seed is applied on skin diseases.

Fresh milky latex of plant is applied to treat skin burns, cuts, wounds, boils, and ringworm.

Latex of plant is applied externally on affected part of mumps and heals foot crack.

Stem bark, leaf, and young shoot pastes used to control bleeding from cuts and wounds.

Stem bark paste along with powdered rhizome of Besar (Curcuma longa L.,), applied externally on cuts, wounds, and skin diseases.

*Rhizome paste applied on ringworm and other skin diseases.

Plant juice used to wash the wounds. Root extract applied over the affected areas on skin allergy.

* Plant paste applied over fresh minor cuts and wounds as antiseptic for quick healing.

*Stem paste applied on skin burn.

Leaf juice applied on prickly heat to get quick relief

Tuber paste applied externally on bois and over tumors (nuts formed by remain parts of spine) to burst out and remove pus and remains of spine.

Paste of entire plant rubbed over affected parts to cure skin inflammations.

The pastes of leaves are used to relieve burning of palm and soles.
Juice of leaves and tender shoots applied externally in skin burns.

Leaf paste is used for boils, blisters, and insect bite.

AGS- 120 
Lycopodium clavatum L.,

Lycopodiaceae. Naagbeli (N/M).

AGS- 197

Melia azedarach L., Meilaceae. Bakain (Th), Rhabenasing (M).

$A G S-41$

Mimosa pudica L., Fabaceae. Boohari Jhar (N), Lajjalu jhar (Th). AGS- 60

Mirabilis jalapa L., Nyctaginaceae. $\operatorname{Malati}(N)$. AGS- 381

Nerium oleander L., Apocynaceae. Karbir (N). AGS- 209

Osbeckia stellata Buch. - Ham., ex D. Don, Melastomataceae Raato Chulsi (N), Aangrik (M). AGS- 225

Oxalis corniculata L., Oxalidaceae. Chariamilo (N), Tinpatiya (Th).

AGS-152

Plumbago zeylanica $L$. ., Plumbaginaceae. Chitu (N), Teete (M).

\section{AGS-173}

Premna barbata Wall. ex Schauer. Verbenaceae. Gineri (N/M). AGS-233

Pterocarpus marsupium Roxb. Fabaceae. Bijaysaal (N/M), Bijjiya (Th). $A G S-377$

Rumex nepalensis Spreng,

Polygonaceae. Halhale (N/TH),

Palungo (M).

AGS-61

Solanum nigrum L., Solanaceae, Bihi (N), Kamai (Th) AGS- 02

Tridax procumbens L., Asteraceae. Kurkure Jhar (N/M).

AGS- 103

Viscum album L., Loranthaceae. Hadchur (N), Hadjor (Th). AGS- 402

Wedlandia puberula DC., Rubiaceae. Seto tilko (N), Kaaiyon (M). AGS- 371

Zizyphus rugosa Lam., Rhamnaceae. Jangali Bayar (N/M), Jhar baiyra (Th). AGS-361

(N= Nepali, $T h=$ Tharu, and $M=$ Magar, *= for new report $)$
Wild, trailing shrub/ Root

Wounds (Oli, 2003); Cuts and wounds (Joshi et al., 2011)

Wild small Leucoderma and wound (Joshi sized treel Leaf and Joshi, 2007) and flower

Wild under shrub/Root and leaf

Cuts and wounds (Panthi and Chaudhary, 2003); Scabies (Acharya and Pokhrel, 2006)

Wild herb/Leaf

Wild shrub/

Leaf and latex

Wild Shrub/

Plant juice

Cuts and wounds (Balami 2005): Cuts, wounds, and scabies (Joshi et al., 2011)

Wild herb/Leaf Cuts and wounds, antiseptic (Panthi and Chaudhary, 2003), Pimples, cuts and wounds (Dhami, 2008); Boils and skin problems (Rokaya et al., 2010)

Wild under shrub/Latex and tender shoot.

Leprosy and skin diseases (Rai, 2003); Ringworm (Joshi and Joshi, 2007); Blister, wart, and ringworm (Bhattarai et al., 2009)

Wild small

sized treel

Wood

Wild tree/ Leaf

Wild herb/ Root Skin diseases (Coburn, 1984); and leaf Cuts, wounds, and swelling (Mahato, 1998); Ringworm (Mahato, 1998); Ringworm
and skin burns (Devkota and Karmacharya, 2003): Eczema (Joshi and Joshi, 2007); Scabies (Joshi et al., 2011).

Wild herb/Leaf Ringworm (Dhami, 2008); and fruit Wounds (Joshi et al., 2011).

Wild herb/ Entire plant

Cuts and wounds (Mahato and Chaudhary, 2003; Acharya and Pokhrel, 2006

Wild semiparasitic climber/Stem and root

Breaks, sprains, and bruises (Coburn, 1984); Boils and wounds (Panthi and Chaudhary, 2003)

Wild small

sized tree/Stem bark

Wild small sized tree/Leaf
Root juice applied externally on cuts and wounds for its fast healing power.

Crushed leaves with water used against pimples, itching, allergy and other skin diseases.

*Paste of fresh leaves is used for healing as antiseptic.

Poultice of flower applied externally on skin eruption.

Root poultice applied over cuts and wounds.

Fresh leaves eaten raw to cure different skin diseases.

*Leaf juice is demulcent and applied over boils.

Leaf paste is used in ringworm.

Latex of plant is used to expel spines from the body.

Plant juice applied externally on affected parts by ringworm.

Leaf juice applied over cuts and wounds.

Juice of fresh plant material is applied topically as antiseptic on wound to stop bleeding from cuts.

Fresh leaf crushed and its juice applied on insect bites, in skin eruptions, and infected portion of eczema.

Milky latex is applied on affected parts of scabies.

Paste of tender shoot is used to treat leprotic wound and skin diseases.

*Wood paste is applied to stop bleeding from cuts and wounds.

*Decoction of bruised leaves is applied on boils, sores, and other skin diseases.

Root paste applied externally on cuts and wounds due to quick healing property.

Fresh leaf juice is applied on cuts, wounds, and muscular swellings

Fresh leaf crushed and made paste, which is used topically in skin diseases, usually when skin has small warts.

Unripe fruit paste is applied on ringworm.

Fresh plant juice is applied externally to treat cuts and wounds.

*Plant paste is applied to treat boils and pimples.

Dried powder of stem and root mixed in mustard oil and applied locally on boils and wounds.

*Stem bark juice is applied externally to treat cuts and wounds.

*Stem bark paste is applied on skin diseases.

*Leaf paste is applied locally in skin diseases. 


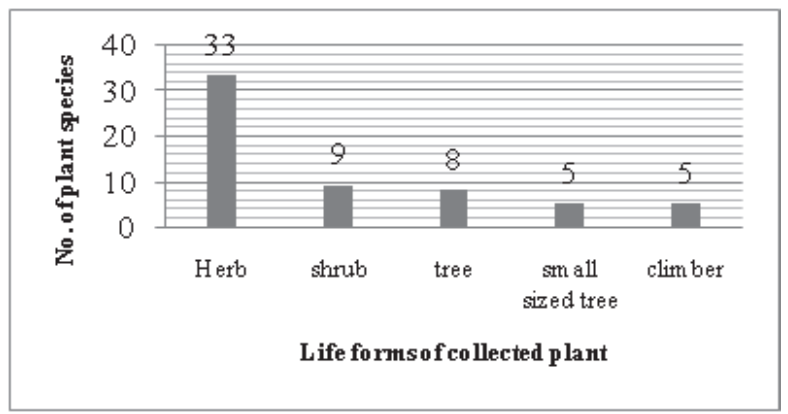

Fig. 2. Growth forms of plants used as medicine in the study area.

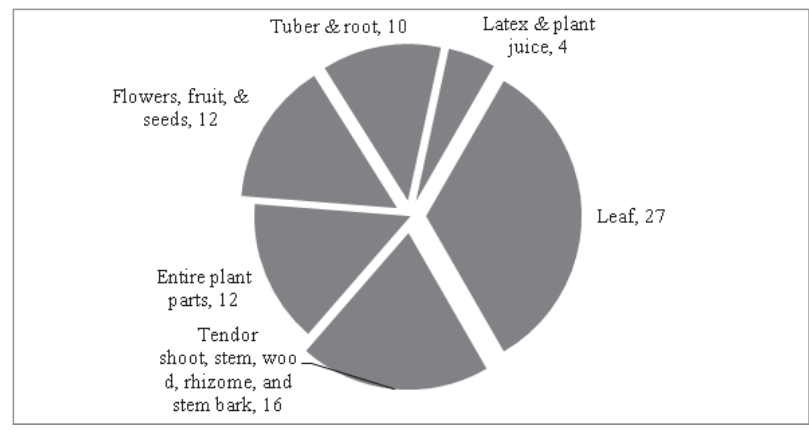

Fig. 3. Plant parts used as medicine in the study area

\section{CONCLUSION}

This study indicated that the study area has plenty of medicinal plants to treat skin diseases. Earlier studies such as Acharya and Acharya, 2009; Singh et al., 2011 a, b, and 2012 etc on traditional medicinal plants also revealed that economically backward and local people of western Nepal prefer herbal medicine due to low cost and sometimes it is part of their social life and culture. It is evident from the interviews conducted in different villages; knowledge of medicinal plants is limited to traditional healers, herbalists, and elderly person who are living in rural areas.

This study concluded that even though the accessibility of western medicine for simple and complicated diseases is available, many people in study areas of Rupandehi district is still continue to depend on medicinal plant for the treatment of some simple skin diseases such as cuts and wounds, boils, eczema, scabies, and abscesses. Well-knowledge healers have good interactions with patients and this would improve the quality of healthcare delivery. As indigenous knowledge on usages of medicinal plants is transmitted without any systematic process and younger generations of the communities are not interested in traditional healing system because it has no/very little scope for money, so they engage themselves in other occupations. It thus becomes, necessary to acquire and preserve this traditional system of medicine by documentation and identification of specimens.

The plant part use in phytotherapy showed that leaf is use in a large number of species followed by stem, stem bark, tender shoot, and rhizome use. Leaf and stem collection if not done carefully then could threaten existence of the species. Debarking or collection of juice /latex could threat the tree if practiced inappropriately. Even more sensitive is the collection of root, rhizome, and tuber. It is learned from the local residents that a large number of medicinal species are collected from these areas for commercial purpose and whole plant harvest makes the largest volume followed by seed, fruit, stem, and tuber.

\section{ACKNOWLEDGEMENT}

The first author (AGS) is thankful to the tribal communities of western Nepal for disclosing secrete of medicinal plant for cure of different skin diseases. AGS is also thankful to Dr. Akhilesh Kumar (NBRI, Luckhnow, India), Dr. J. P. Tewari (Retd. Professor of Botany, M. L. K. P. G. College, Balrampur, India), Dr. M. P. Panthi, Mr. B. R. Nepali, and Mr. L. P. Gautam of Butwal Multiple Campus, Tribhuvan University, Nepal. for identification of plant specimens and in preparation of manuscript. The authors also acknowledge the help provided by the local people and senior citizens for carrying out the exploration activities.

\section{REFERENCES}

Acharya, R. and Acharya, K. P. 2009. Ethnobotanical study of medicinal plants used by Tharu community of Parroha VDC, Rupandehi District, Nepal. Scientific World. 9: 81-85.

Acharya, E. and Pokhrel, B. 2006. Ethnomedicinal plants used by Bantar of Bhaudaha, Morang, Nepal. Our Nature. 4:96-103.

Adhikari, B. 2003. An Introduction to Nepalese Siris (Albizia species). Botanica Orientalis. pp. 76-79.

Baral, S. R. and Kurmi, P. P. 2006. A compendium of medicinal plants in Nepal. Publisher: Mrs. Rachana Sharma, 281, Maujubahal, Chabahil, Kathmandu, Nepal.

Balami, N. P. 2005. Ethnomedicinal uses of plants among the Newar community of Pharping Village of Kathmandu district, Nepal. Journal of Tribhuvan University.

Bhattarai, S., Chaudhary, R. P. and Robin, S. L. Taylor 2009. Ethnomedicinal plants used the people of Nawalparasi district Central Nepal. Our Nature. 7: 82-99.

Coburn, B. 1984. Some Natural Medicinal Plants of Western Gurung. Kailash. 11(1-2): 55-87.

Dhami, N. 2008. Ethnomedicinal uses of plants is Western Terai of Nepal: A case study of Dekhatbhuli VDC of Kanchanpur district. In: Medicinal plants in Nepal: An Anthology of Contemporary Research (Eds.) Jha, P. K., Karmacharya, S. B., Chhetry, M. K., Thapa, C. B. and Shrestha, B. B. Ecological Society of Nepal (ECOS) P.O. Box 6132, Kathmandu Nepal. pp: 165-177.

Devkota, R. and Karmacharya, S. B. 2003. Documentation of Indigenous Knowledge of Medicinal plant in Gwallek VDC of Baitadi district Far-Western Nepal. Botanica Orientalis. pp: 135-143.

District Development Committee. 2007. District Profile of Rupandehi, Government of Nepal.

Gunerantnne, A. 2002. Many tongues one people; the making of Tharu identity in Nepal. Ithaca, New York, Cornell University Press. pp:2224

Gurung, K. 2003. "Indigenous Knowledge on the Plant Resources Used By The People of Tinjure Area, Tehrathum district, Nepal". 
Botanica Orientalis. pp: 118-125.

Joshi, A. R. and Joshi, K. 2007. Ethnomedicinal Plants used against skin diseases in some villages of Kali Gandaki, Bagmati, and Tadi Likhu water sheds of Nepal. Ethnobotanical Leaflets. 11: 235-246.

Joshi, N. R. and Singh, V. 2010. Non-timber Forest Product used by Tharu tribe of Kanchanpur district of Far-Western Nepal. New York Science Journal. 3 (11): 111-119.

Joshi, K., Joshi, R. and Joshi, A. R. 2011. Indigenous knowledge and uses of medicinal plants in Macchegaun, Nepal. Indian Journal of Traditional knowledge. 10:281-286.

Kunwar, R.M., Chaudhary, C. L. and Bussmann, Rainer. 2008. Diversity, Utilization, and Management of Medicinal Plants in Baitadi and Darchula districts, Far- West Nepal. The initiation. SUFFREC: 157-164.

Kunwar, R. M., Shrestha, K. P. and Bussmann, R. 2010. Traditional herbal medicine in Far-West Nepal: A Pharmacological appraisal. Journal of Ethnobiology and Ethnomedicine. 6:35.

Lev, E. 2006. Ethno-diversity within current ethnopharmacology as part of Israeli traditional medicine. A review. Journal of Ethnobiology and Ethnomedicine. 2:4.

Mahato, R. B. 1998. Notes on some plants of ethnomedicinal importance from Palpa district. Tribhuvan University Journal. 21 (1): 71-76.

Mahato, R. B. and Chaudhary, R. P. 2003. Ethnomedicinal study and antibacterial activities of selected plants of Palpa district, Nepal. Scientific world. 2: 38-45.

Manandhar, N. P. 1993. Herbal remedies of Surkhet district, Nepal. Fitoterapia. 64 (3): 265-272.

Manandhar, N. P. 1998. Native phytotherapy among the Raute tribes of Dadeldhura district, Nepal. Journal of Ethnopharmacology. 60: 199-206.

Manandhar, N. P. 2002. Plants and People of Nepal. Timber Press Oregon, U.S.A. 599

Martin, G. J. 1995. Ethnobotany: A method mannual. In A People and Plant Conservation Mannual. Chapman and Hall, London.

Noltie, H. J. 1994. Flora of Bhutan Vol. III Part I. Royal Botanic Garden, Edinburgh, and Royal Government of Bhutan.

Oli, B. R. 2003. Ethnomedicinal uses of plants among the Limbus of Hellock Area of Tapethok V. D. C., Taplejung, Nepal. Botanica Orientalis. 52: 279-292.

Panthi, M. P. and Chaudhary, R. P. 2003. Ethnomedicinal Plant Resources of Arghakhanchi District, Western Nepal. Ethnobotany 15 : 71-86.

Polunin, O. and Stainton, A. 1984. Flowers of the Himalaya. Oxford University Press, New Delhi, India.
Rai, M. B. 2003. Medicinal plants of Tehrathum district, Eastern Nepal. Our Nature. 1: 42-48.

Rai, S. K. 2004. "Medicinal plants used by Meche people of Jhapa district, Eastern Nepal". Our Nature. 2: 27-32.

Rajbhandari, K. R. 2001. Ethnobotany of Nepal: Ethnobotanical Society of Nepal.

Rao, R. R. 1996. Traditional Knowledge and sustainable development key role of ethno-biologist, Journal of Ethnobotany. 8:14-24.

Rao, R. R. and Sharma, B. D. 1990. A manual for Herbarium Collections. India: Botanical Survey of India.

Rao, C. K. 2004. Flora; A Gardener's Encyclopedia, India. Om Books Service.

Rokaya, M.B., Munzbergovaa, Z. and Timilisina, B. 2010. Ethnobotanical study of medicinalplants from the Humla district of western Nepal. Journal of Ethnopharmacology. 130: 485-504.

Ross, I. A. 1999. Medicinal Plants of the World, USA, Human Press.

Sapkota, P. P. 2008. Ethnoecological observation of Magar of Bakuni, Baglung, Western Nepal. Dhaulagiri Journal of Sociology and Anthropology.Vol. 2: 227-252.

Sen, P. 1993. Therapeutic potentials of Tulsi: from experience to facts, Drugs News and Views. 1(2): 15-21.

Singh, A. G., Panthi, M. P. and Tewari, D. D. 2011. a. Ethnomedicinal Plants Used by the Tharu and Magar Communities of Rupandehi District, Western Nepal. Current Botany. 2 (2): 30-33.

Singh, A. G., Poudyal, K. N. and Tewari, D. D. 2011 b. Diversity of cultivated and wild medicinal plants used by people of Devdaha VDC of Rupandehi District, Western Nepal. Current Botany. 2 (2): 34-42.

Singh, A. G., Gautam, L. P. and Tewari, D. D. 2011 c. Folk uses of some medicinal of Dobhan VDC of Palpa distric, Western Nepal. Journal of Phytology. 3 (8): 62-67.

Singh, A. G., Kumar, A. and Tewari, D. D. 2012. An Ethnobotanical Survey of medicinal plants used in Terai forest of western Nepal, Journal of Ethnobiology and Ethnomedicine.

Stainton, A. 1988. Flowers of the Himalayas: A Supplement, Oxford University Press, New Delhi, India.

The International Plant Names Index 2008. http:/www.ipni.org

Uprety, Yadav, Emmanuel, K., Boon, R. C., Poudel, R. C., Shrestha, K. K., Rajbhandari, S., Ahenken, A. and Tiwari, N. N. 2010. Nontimber forest products in Bardiya district of Nepal: Indigenous Use, Trade and Conservation. Journal Human Ecology. 30 (3): 143-158.

Watanabe, T., Rajbhandari, K. R., Malla, K. J. and Yahara S., 2005. “ $A$ handbook of Medicinal Plants of Nepal", Ayur Seed Life Environment Institute, Japan. 262.

Woodland, D. W. 1997. Contemporary Plant Systematics. Andrews University Press, Berrien Springs, Michigan, USA. 